\title{
Relations in the Communication Networks Centrality for Disaster Risk Reduction
}

\author{
Damayanti Wardyaningrum ${ }^{1, a)}$ \\ ${ }^{1}$ Universitas Al Azhar Indonesia \\ a)damayanti@uai.ac.id
}

.. DOl: https://doi.org/10.18196/jkm.111016

Article Info

Article history: Received 26 Dec 2018 Revised 12 April 2019 Accepted 7 May 2019

\section{ABSTRACT}

The communication network in a disaster area could help the local people to reduce the risk by providing information and aid. The purpose of the research is capturing the communication network of the people in the natural disaster area of Mount Merapi in Central Java. Kalitengahkidulwas one of the worst affected villages byMerapi eruption in 2010. This location has been acknowledged as a red zone, but the local people decided to stay because of historical and economic reason. The research focuses on identifying the centralization of communication network, notably regarding the evacuation training as one of the preventive action in disaster risk reduction. The study uses the post-positivist method and survey and interview for data collecting. The research finds that the people's relation in the disaster evacuation training is spread or diffused to many actors, consisting of local people and outsiders. While local people comprise ordinary residents and higher village officer, the outsiders include local government, university representations, and volunteers. The messages delivered in disaster evacuation training ranges from a list of name that should be called when signs of a disaster appeared, activities and individual that become the priority in the evacuation process, evacuation route, and accommodation in the evacuation center. Relations in the decentralized communication network could reduce disaster risk by employing local capacity.

Keywords: centralization in communication network; disaster risk reduction

\begin{abstract}
ABSTRAK
Jaringan komunikasi masyarakat di wilayah bencana memberikan manfaat untuk pengurangan risiko bencana baik untuk ketersediaan informasi maupun pertolongan. Penelitian bertujuan memperoleh gambaran relasi dalam jaringan komunikasi masyarakat di wilayah rawan bencana alam gunung Merapi Jawa Tengah. Dusun Kali tengah kidul sebagai objek penelitian merupakan wilayah terparah dilanda bencana pada erupsi besar tahun 2010 yang kini telah ditetapkan sebagai zona merah. Fokus penelitian pada identifikasi sentralitas jaringan komunikasi tentang latihan evakuasi sebagai salah satu tindakan preventif pengurangan risiko bencana. Metode penelitian menggunakan post positivis dengan pengumpulan data melalui survey dan didukung wawancara. Relasi masyarakat pada jaringan komunikasi tentang latihan evakuasi bencana terdesentralisasi atau menyebar kebanyak aktor yang terdiri dari warga local maupun warga dari luar dusun. Aktor local terdiri dari warga biasa dan warga yang memiliki posisi di struktur sosial. Sementara actor dari luar dusun berasal dari instansi pemerintah daerah, relawan bencana dan orang-orang dari perguruan tinggi. Pesan-pesan yang disampaikan dalam latihan evakuasi bencana meliputi, siapa yang harus dihubungi saat ada tanda-tanda bencana, siapa saja dan apa saja yang menjadi prioritas dalam proses evakuasi, dimana saja tempat evakuasi, jalur evakuasi mana saja yang dapat dipilih, dan akomodasi ditempat evakuasi. Relasi dalam jaringan komunikasi yang terdesentralisasi kepada banyak actor merupakan potensi untuk mengurangi risiko bencana dengan menggunakan kapasitas lokal.
\end{abstract}

Kata kunci : sentralitas jaringan komunikasi; pengurangan risiko bencana 


\section{INTRODUCTION}

Indonesian Act no. 24 of 2007 regarding Disaster Management suggests disaster risk reduction to be systematic acts for developing and applying policies, strategies, and actions that could reduce disaster vulnerability and risk that people face. With this in mind, enhancing people resilience is essential preparation to take. By having community-based implementations of disaster risk reduction, corroborating the capacity of disaster-prone people is considered demanded because people resilience is the necessary prerequisite of a stable and tenacity country.

As the first step in generating disaster prevention capacity, the government shifts the paradigm that initially put pressure on responsiveness to prevention by focusing on relevant attempts towards disaster risk reduction. The government directs the execution of Indonesian disaster prevention to "establishing national resilience towards disaster" by employing a strategy that alienates disasters from society and fosters harmonious coexistence of disaster-related residents with natural catastrophes. It can be realized by encouraging people capability in adapting to various possible outbreaks and maximizing the role of local wisdom (Maarif, 2012)

Span et al. in Sinulingga et al. (2014) also emphasized the involvement of local people in a disaster management network. The role of management principally is to arrange the sector of local society that calls for sector involvement in supporting the functions. A network in the sectoral development of local people will create a unique mechanism in the sectoral improvement of the local society itself. Residents possess a strategic position in building the management of a state, notably if it is supported by a broad network since it will enhance the outcome of the mechanism that affects the organization's characteristics and performance.

That understanding is also conceived by Budiarti \& Riskha (2012) that identified that the deciding factors of successful disaster management and recovery project after the Merapi eruption was vital preparations for disaster risk reduction, coordination and collaboration, the participation of and contiguity with society, as well as dedication of human resource as the project executant. Varda (2008) found that, from his investigation on Katrina storm in the United States in 2005, killing almost 2000 lives, informal relations among individuals and groups play a significant role in managing a disaster independently. Regardless of the help from the government, individual capability (apart from the skill to earn income and level of education) in coping with destruction after a disaster is irresistible. Likewise, Garnet \&Kauzmin (2007), which also examining Katrina storm from communicative crisis perspective, contended that inclusion of transparency, technology, chronology, planning, and response on the selection stage might present communicative crisis as a network among the organization.

Lestari et al. (2012) emphasized, after studying the phases of emergency response on Mount Merapi disaster, the substantiality of disaster communicative management that has been started since the planning stage to execution, coordination, and evaluation. In this vein, planning has been carried out when even signs for disaster have not emerged. Based on the previous experience on eruptions, planning is indispensable to be done as a preventive action to halt the loss of more lives and wealth.

Maloney and Coppola (2009), after identifying his findings in several regions that have undergone disaster, affirmed that disaster management can allow society to contribute by giving them special workshops so that they are prepared and gain ability in reducing the risk of disaster; starting from the time when a disaster has not come to the time when it will be happening. When a disaster occurs in some region, society could be saved because there is local wisdom believed. Consider community in Simeleu in Aceh as an example; by relying on their traditions, they unbelievably saved themselves in a 2004 tsunami, which made more than 200.000 people past away. Society in Simuelelu inherits the knowledge of tsunami signs that they elicit from their predecessor. Another striking example is the early warning system that is socialized regularly in Van Wet Country Ohio successfully save a group from a tornado in November 2002 despite the high number of the buildings which destroyed.

Maloney and Copllo in Wardyaningrum (2016) also discovered that, from their research on many disasters where the society is saved, a method which can be used to appraise local potency in dealing with disaster is by exerting communication network map. The network of communication's plan is likely to map the potency of the community, ranging from the individual level to group, in 
performing disaster mitigation. Communication network could depict much essential information, ranging from a picture of how society behaves toward information regarding disaster evacuation training to how residents could access experts who well-informed in the process of evacuation. Moreover, it can demonstrate the figures that can be relied on and called concerning disaster evacuation practice and the most effective communication tools which can be useful for each phase of disasters. ,

Andersen's analysis in Lawan (2005), exposing the function of the network, is also relevant to study on a communication network and its relevance in the disaster context. It reported that in a network, there is an informative function called media of information or network of information enabling each stakeholder in the network gain knowledge relating to the problem or other opportunities about business activity. It is called the lubricant function.

Besides, through the pattern in the network of communication, the stages of information can be disseminated, and the persons who play a significant role in spreading the data can be elicited. A study on a network of entrepreneurs shows that two stages of the communication might be realized in two types of different network mechanism. Firstly, the transfer of information to a group might be delivered through the opinion of the leaders. Secondly, the exchange of information can happen among members of groups which have similar positions. Leaders' view in a network can be functioned as brokers, as occurred in a business network because they could access external camps (Burt, 1999).

In a calamity, much information is required by residents to survive in stressful situations. Society needs to respond to disaster using the information to take proper steps. For example, the information about evacuation time, a safe place for constructing shelter, how to deal appropriately with victims, build a building that is immune from an earthquake or other disasters. Quarantelli (2005) reminded the importance of studying many studies or research on previous accidents to achieve more formal knowledge of disaster prevention.

Respond of society and process of disaster adaption, as well as disaster analysis prediction and its management can be carried out by examining a structure of network and people sociodemographics. In addition, the social network owns palpable contribution toward individuals' and groups' capability to survive and surmount emergency on phases on catastrophe and give practical advantage for aids. Besides the potency of residents in a disaster and decentralized help formation can be identified through the social network, it also offers appropriate disaster prevention training program (Varda, 2008; Ozerdam\& Jacoby, 2006; Magsino, 2009). A Social network that is applied as a communication network in a structure can be used in any context, including in the natural catastrophe.

The research was performed in the disaster-prone region Mount Merapi volcanic mountain, central Java. As one of the region which experienced the most damaging effect in 2010 eruption, Kalitengahkidul village's residents should be cautious toward the constant eruption threats considering Mount Merapi is one of the most active mountains in the world. In 2010 eruption, almost all village people were intact although the evacuation was late. Unfortunately, the residents cannot evacuate their goods as assets to earn income, such as livestock and farm. After the accident, the people could have the opportunity to practice evacuation training to face the next threat. Of many practices conducted, the research was carried out to investigate a network of communication that is computed by focusing on the network centrality.

Furthermore, Carolan in Eriyanto (2014) found that the measurement of network structure on network concentration is centralization. Centralization refers to how concentrate a network on some actors (node): do a relation within a network disseminates to many people or focus to only some people? A network is called centralized if it merely consists of some individuals. By contrast, a network can be called decentralized if the ties lead to more people.

Centrality points out the status of the actors in a whole network, such as how central an actor in a network and who is the most prominent and deciding actor in a network. Also, by taking over the more central position, a leader might own more opportunity to look for resources (friends, experts, and so on) and is more accessible in gaining access to information or support from the social network. By having more connections, it can elevate the leader's chance of obtaining access to rare information. Access toward the diverse resource provides a leader with an opportunity to dispose of it to the stream of information available within a group or a team.

The importance of centrality in a network was affirmed by Borgatti\& Everett as cited in Valente (2010) regarding centrality that in a network of individuals that stand in a central position 
become completely vital because many people wish to know the person who stands in a central location and work as the leader. Moreover, Freeman explained that centrality could be determined easily by identifying the number of persons who choose specific individuals in a network. Another measure for centrality is betweenness or indicator which deciding how far the position of a man among other people in a network, and closeness is an average distance between a person with another person in a network. The concept of centrality in a network turns to be critical to be examined further, especially regarding the pattern of centrality in which lies other actors figuring in providing an image on network structure and changes affecting people behaviors in a network. Besides that, a member included in a central position could share significant influence towards the speed of behavior change, as well as the tendency in the formation of homophilic relation.

Carolan (2014) even mentioned that centrality is the final element in a study toward the communication network structure. Higher or lower centralization is more determined by power. A more top centralization position has fewer actors with more significant influence and control. Network centrality is measured by deciding which individual those gain the highest score. Subsequently, the discrepancy is added and split with the maximum sum, which theoretically will appear in a network.

From the analysis, the aim of the research was, firstly, acquiring a picture regarding the communication network centrality of disaster evacuation training, and, secondly, identifying actors standing in a communication network, especially relating to out-degree centrality and in-degree centrality. Finally, the study tried to find messages that stream in a communication network.

The research used the post-positivist method which developed from previous research concerning the communication network of society in the disaster-prone region (Wardyaningrum, 2016). A survey was conducted to collect communication network data in 176 residents, and the respondent criteria are that they were at least 17 years old when the big eruption happened. The catastrophe has put the trauma to the local people so that their memories on that event hinged on their mind very clearly. A survey regarding a communication network included questions concerning the man or woman that are called for disaster evacuation training.

For completing and confirming the survey about communication network, interviews were carried out towards nine people, ranging from ordinary residents to figureheads, such as the block leader, hamlet leader, and the village chief, and disaster volunteers. The interview was necessary because, according to a survey, a communication network only access relations and actors. To that end, a more completed description concerning connections made and the persons or the roles which owned by the actors in a network is vital and needed. From the outcomes of interviews, a broader picture of the background of the formation of communication network structure can be acquired.

\section{ANALYSIS}

The analysis of the communication network on disaster evacuation training at the research concentrated on the elements of the communication network centrality. Sub-elements investigated in the communication network, apart from examining centrality structure, discussed the actors standing on the central position of a communication network, including the roles of each actor and message lying in the communication network.

\section{Communication Networks Centrality}

The followings are the picture of the communication networks of the information of society regarding disaster evacuation training: 

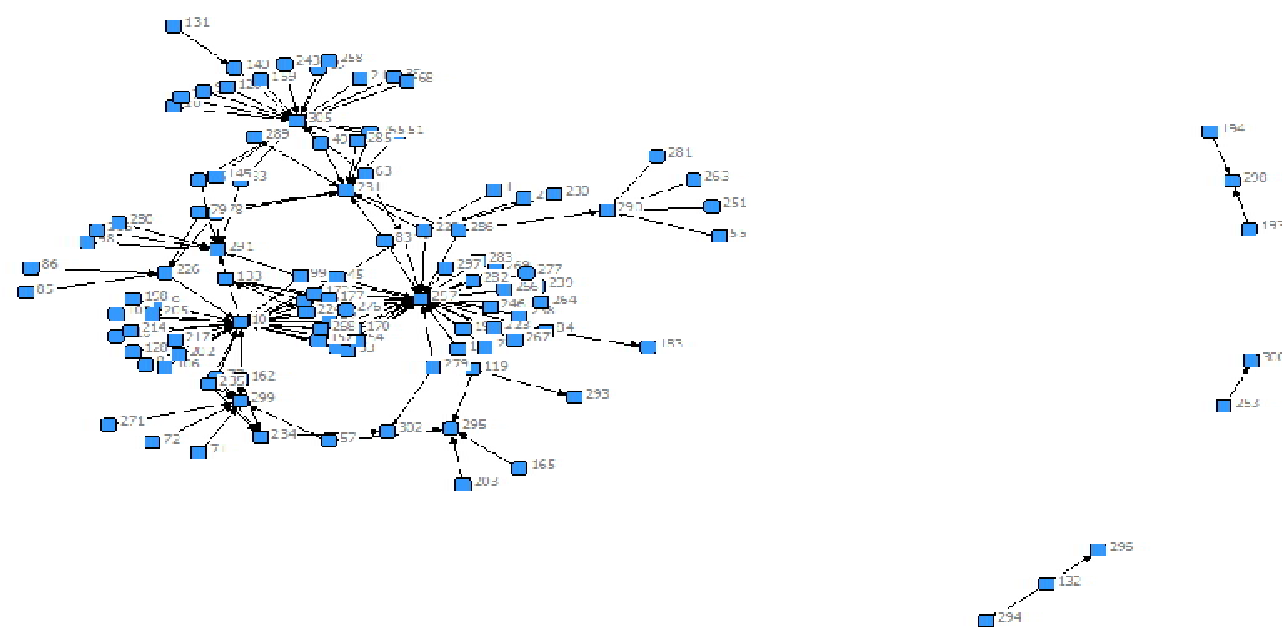

Figure 1.The communication network of the information of society regarding disaster evacuation practice.

The communication network on evacuation training was compounded in the normal phase, namely a period when the activity of eruption has been worn off, and the residents had been able to do their businesses back in the former region of disaster although the land was decided as a red zone. This phase was significantly extended, proceeded contiguously with the disaster recovery phase, and vulnerable to cold lava when the rain comes. Also, there might be threats from advanced eruptions, which made the people should remain cautious. Most of the farm region, which directly affected with volcanic material, had not been able to be planted yet in a one-year or more period. People houses can be reconstructed again after at least four years because of economic and infrastructure challenges, such as roads and bridges that mostly were still in repair.

From the picture of network communication of evacuation training, it was found that almost all actors related to other actors who concentrated on a network. Only eight actors did not relate to another network although it was still tied in the component so that isolated or separated actors were not found. From other related research, actors connected with the network are likely to be safe as opposed to actors which separated from the network. Therefore, the research outcome was relevant with the real condition of the people in the Kalitengahkidul village which almost all of the residents were safe and sound in the 2010 eruption even though their goods cannot be evacuated.

The next examination was to decide actors' positions in a network pictured as centrality or concentration, where other actors concentrated on certain actors. The measurement of communication networks centrality discovered that many actors took over the central positions, namely the easiest or the most common place to be called by the people regarding the information on disaster evacuation training. Actors whowere in the central position in a network would be easier to be called and called other factors, compared to other actors who stood in the outskirts of the network. Moreover, actors in the central position frequently tended to be more accessible and more noticeable by many different actors, as well as more comfortable to gain access to information or resources.

Based on the result of the mapping of communication network on the research, it was found that the communication network centrality of disaster evacuation training spread to many actors or inclined to be decentralized. Actors which occupied central positions were not small but plenty. With low centrality, all actors in the network relied not only on some actors but also from many. With this in mind, power and control on the information or resource did not concentrate on a few actors so that actors in the network had alternatives of information and resources. In the situation of disaster evacuation, the necessary information should be available, fast, and valid because the resident would keep up with the big eruption time. Type of information needed, for example, was the time for evaluation, the shelter places, and the people who were prioritized to be evacuated, and so on. For essential resources needed in the evacuation were transportation for evacuation, foods, medicines, sanitation, and etcetera. 
1. Actors in the Central Position of Communication Network

Based on the measurement of centrality, actors in the network of communication consisted of three categories. Firstly, actors who occupied a position as the formal leader, such as the city government, hamlet leader, or block leader. These actors took central areas in the communication network not only because they had power of information and resources, but also, on the one hand, these actors had decent relations with the local government both in the level of districts and city, which in the end could ease them to gather strategic information regarding the aid and security for facing disaster, and, on the other hand, these actors also had appropriate relations with the villagers. In everyday activities, they understood the condition of their people, played a significant role in helping the people in the emergent period, and supported the villagers to rebuild their regions after the 2010 eruption. One of the attempts that made the village chief regained people loyalty again was the idea of building electricity and roads, which in the beginning was funded independently by the villagers. It suited with a concept which claims that centrality is tightly related to control and powers.

A concept publicized by Burt then becomes relevant with this research because, through the pattern of communication network, not only a sequence of transfer can be spread and the person who has an essential role in spreading the information can be recognized, the transmission of information to the group which occurred through leaders' opinion could be identified. Against the background of the research, this exchange of information disseminated through actors which structurally took a role as the leaders. Furthermore, transfer of information occurred among equal group member. There was a case when an ordinary resident took a big part in transferring information to other actors because the position is similar to other actors.

From his research, Burt found that opinion leaders in the network can figure in being brokers as in the business network because of the access with the external camps. In this vein, the village's opinion leaders had roles as brokers in obtaining information and resources owing to their access to the local government, volunteers, and camps outside the town.

Secondly, actors occupying the central positions in the networks were average residents. Those actors picked the place because other actors in the network entrusted them. These individuals could give help, had valid information on disasters, or persons that were deemed for having relations with structural actors. Another factor which allowed an ordinary resident to place the central position was the closeness with many actors. For example, they were closed because of family connection, kinship, or neighborhood. This condition is relevant to other research that reports that a man tends to believe in or rely on information from familiar or similar persons.

Thirdly, the actors in the central position were people from outside of the village but can be relied on for help, such as disaster volunteer. Besides, there were actors coming from universities that visited the hamlet regularly and was welcomed by the residents because of the information, capacity, and resources they owned for evacuation. In light of that, centrality mentioned by Carolan on higher centralization would position fewer actors with more significant power and control. In the vein of the research, with many actors stood in the central position, the authority and power of information and resources reduced. Actors in the network of communication had more choices to gain knowledge and resources because the control of those two needs spreads to many actors.

In the context of disaster with low communication network centrality, it eased actors in the network to gain access of information and resources since in the situation with a high level of uncertainty, fast and accurate access of information to receive aid was necessary.

\section{In-Degree Centrality and Out-Degree Centrality}

After considering the actors, the next centrality measurement was divided into two types of centrality, namely in-degree centrality and out-degree centrality. In-degree centrality showed the communication of active actors who delivered information. From the out-degree perspective, the actors were the people who had structural positions in the village, ordinary villagers, and people outside the hamlet. Those actors actively visited and socialized the resident to make them participated in the disaster evacuation training. They could come from the local government, university students, or lecturer from UniversitasGadjahMada or the office of regional disaster prevention (BPPD), or volunteers. The presence of external actors prompted the source of information in the communication network to become more promulgated

By contrast, from the in-degree centrality perspective, the actors were ordinary people, mostly women who worked as housewife concurrently. Although actors in the category were more passive in the socialization about disaster evacuation training, they were the hub of questions and often got 
called by other actors because they were conceived having reliable information. These actors had considerable access toward other members in other communication networks and became the reference or the most called person. Relations which were established among them occurred through daily activity, such as visiting or giving aid. Another prominent reason is that those actors often participated actively in the women groups, incorporated in the Family Welfare Guidance Program (PKK) and Integrated Regular Health Care Post (Posyandu).

The followings are the actor's name identified by the centrality measurement in-degree centrality and out-degree centrality.

\begin{tabular}{|c|c|}
\hline In Degree Centrality & Out Degree Centrality \\
Sumi, Ninik, Endang, Tarjo, Indah,Warno, & Jamin(Hamlet Leader), Suroto(Village \\
MaryonoPaiyem, Kusmiyati, Wakiyem & chief), UGM,Sugiyanto, BPBD, \\
Volunteer,Saejono, Riyadi, Sugiyono, \\
The Local Government
\end{tabular}

Figure 2.Actors name identified by the centrality measurement in-degree centrality and out-degree centrality.

By scrutinizing the actors' distribution filling the central position in the communication network established, it can be said that it corresponds with Valente's account (2010) on the significance of centrality which emphasizing that actors in the central position can significantly affect the speed of behavior changes. With the experience of 2010 eruption and the stipulation of some regional condition to be a disaster-prone area, people capability to acquire behavior change in dealing with many disasters possibilities can increase. The changes in behavior mentioned included being relentlessly alert on information concerning the changes in Mount Merapi mountain's activity, raising one's alertness on self and family evacuation, and being sensitive in treating nature in an exploiting way that may cause a further catastrophe, such as cold lava and avalanche. Hence, communication is a reliable social capital in the surrounding society (Wardyaningrum, 2016).

Moreover, the actors' density in a region that not spread to only structural actors is consistent with Carolan's study (2014). The study asserted that although a network might be dense, it may have lower centrality concurrently (the relations are promulgating until crossing actors networks) and induces smaller links which concentrate on some actors only.

On the other hand, Leavit and Khadusin (2012) contended that, based on the classic research, centrality with many variations in form have some substantive implications. The centrality which spreads will create independence of networks members, increase the activity of networks member, enable many missteps, slow down the organization, and omit leaders regardless of higher satisfaction of each member. Furthermore, Khadusin analysis of "wheel" network, or a network where one person directs an individual, held that organization would be more effective despite the satisfaction which will be experienced by each member. Dynamics occurring in the society in this region had some substantial implication from centrality created, including independence of some actors. For instances, 8 actors were not entangled in a network and only accepted one leader for each member. The error which might arise because of lower centrality probably is that the people would not be safe when a catastrophe happened because they were isolated from the network.

Independence also can be seen from some residents that did not join in the communication network and participated in the evacuation training. The interviews showed that there remained some reluctance in them for participating in the evacuation training. Those people generally knew about the evacuation training but believed that what they had witnessed in 2010 had given them proper experience regarding evacuation. It occurred in 2014 eruption when the people had evacuated their family without using village facilities. Mostly, the residents had gained better preparations in facing volcano so that some resident felt that evacuation training was dispensable because there would be no practical information learned. 
However, some people did not realize that disasters do not ensue in the same form invariably, although they might occur in the same region. There were many inadequacies from previous disaster prevention, which eventually fostered the local government and related institutions to facilitate the people to participate in disaster evacuation training for gaining new skills and knowledge. Considering the explanation on communication network above, the researcher affirmed that the communication network could raise people awareness on the significance of the training for sustainability. Because they lived in a disaster-prone area, they should ceaselessly be cautious even though there were no signs of eruption. The reason is that many threats can happen any time, such as cold lava and avalanche, caused by sand mining process in post-eruption time. Through actors laying on central positions, homophile relations can be realized. In this context, the people relation did not depend on the same situation but also interests. For example, the same enthusiasm to create communal alertness, the same understanding on dealing with disaster, and the same hope for the posteruption period.

3. Messages in the Communication Network of Disaster Evacuation Training

In the disaster evacuation training, actors would gain new much information regarding the disaster proneness of their area and the capability owned by the resident to face disaster. Firstly, actors would acquire a picture of the potency of the eruption, which might happen randomly and utterly different from previous outbreaks. Society did not receive a direct explanation regarding disaster potency because they had never put up with a big eruption before 2010 eruption happened, even for the elderlies. Also, disaster threats would not be only MountMerapi eruption but also avalanche and cold lava because of exploitative sand mining.

Secondly, the residents should recognize signs which mostly always appeared before the eruptions and heeded the government advice. The signals of increased activity of MerapiMountain were followings: incandescent lava, vibrations, roar, smokes, and etcetera. Besides, there were warnings on when the residents should avoid some regions and evacuate, and there were instructions on the evacuation path which safe to be used, shelter locations, and the methods to obtain logistic and sanitation.

Thirdly, when Merapi Mountain was starting to erupt, the people should understand the persons who can be called to acquire help. Other information needed is that the actions that should be anticipated by the people, and the interim evacuation places, and the activities which should be eluded because of its dangerous effect, such as avoiding an area within specific kilometers. Finally, another essential information that should be delivered within disaster evacuation training is that the individuals who should be prioritized in or were vulnerable to the process of evacuation, such as children, pregnant and breastfeeding mother, seniors, and disabled.

\section{CONCLUSION}

According to the communication network structure of disaster evacuation training, almost all actors were connected to the networks. The hamlet-dwellers then tended to be safe and secured in the projected disaster because, although few actors were separated from the network, they were still related to the component or with other actors.

The communication network centrality of disaster evacuation training in the Kalitengahkidul, Sleman, Central Java, was remarkably low or it was decentralized to many actors in the communication network. Actors who occupied the central position were local actors and actors originated not come from the hamlet. Local actors consisted of regular residents and residents who owned a position in the social structure while actors who not were from the village come from the local government, disaster volunteer, and universities participants. Low centrality gave an excellent opportunity to the promulgation of power and control of information and resources that were needed by the people in the disaster. The residents had diverse alternatives for information resources because there were actors who could be called and deemed helping when the accident happens. That condition supported the establishment of local capacity in building the capability of society capacity in reducing disaster risks independently.

Potency from communication networks on disaster evacuation training can be used to develop socialization regarding various practice for society relating to disaster evacuation, for instance, 
socialization on disaster-prone regions, introduction to the continuous early disaster warning system, effective evacuations methods, and so on. These training, which was done by using the capacity of the communication network, could improve people potency that is safe when the accident happen and to secure the goods so that the disaster risk reduction run effectively.

Low communication network centrality or decentralization opened the opportunity for the changes of behavior of society on disaster risk reduction to be more productive and efficient than before. Actors who occupied the central position in the communication network could affect local community to build the capacity.

Messages delivered in the disaster evacuation training could be developed for providing new knowledge of modern knowledge-based disaster evacuation which could proliferate the capacity of local people, including the use of communicative technology which is likely to fasten the access to elicit information and elevate the independence of disaster risk reduction. According to the communication network structure of disaster evacuation training, almost all actors were connected to the networks. The hamlet-dwellers then tended to be safe and secured in the projected disaster because, although few actors were separated from the network, they were still related to the component or with other actors.

\section{REFERENCES}

Budiarti, Riskha Tri. (2012), Mengidentifikasi Faktor-faktor Penentu Bagi Kesuksesan Proyek Pengelolaan Bencana :Studi Kasus Pengelolaan Pemulihan Pemulihan Pasca bencana Letusan Gunung Merapi di Indonesia, Program Magister Sains Fakultas Ekonomi dan Bisnis Universitas Gadjah Mada Yogyakarta.

Burt, Ronald S, (1999). The Social Capital of Opinion Leaders, Annals of the American Academy of Political and Social Science, Vol. 566, Sage Publications, Inc. \& American Academy of Political and Social Science.

Carolan, Brian V, (2014), Social Network Analysis and Education, Theory, Methods \& Application, Singapore, SAGE Publication.

Eriyanto (2014), Analisis Jaringan Komunikasi, Strategi Baru dalam Penelitian dan Ilmu Sosial Lainnya, Jakarta, Prenada media Grup

Garnet \&Kouzmin, (2007), Communicating Throughout Katrina: Competing and Complementary Conceptual Lenses on Crisis Communication. Public Administration Review, Vol 67, Special Issue on Administrative Failure in the Wake of Huricane Katrina (Dec, 2007), pp 171-188. Published by Wiley on behalf of the American Society for Publiv Administration Stable.

Khadusin, Charles (2012), Understanding Social Networks, Theories, Concepts and Findings, New York, Oxford University Press.

Lawang, Robert, M.Z (2005), Kapital Sosial dalam Perspektif Sosiologi, Universitas Indonesia, FISIP UI Press,

Lestari, Puji, Prabawa Agung, Wibawa Arif (2012), Manajemen Komunikasi Bencana Merapi 2010 pada saat Tanggap Darurat,Jurnal Ilmu Komunikasi, Volume 10, No. 2.

Maarif, Syamsul (2012) Pikiran dan Gagasan, Penanggulangan Bencana di Indonesia, Jakarta, Badan Nasional Penanggulangan Bencana.

Magsino,Sammantha L (2009 ), Applications of Social Network Analysis for Building Community Disaster Resilience, Board on Earth Sciences and Resources Division on Earth and Life Studies The National Academic Press, Wahington DC.

Maloney,Erin K \& Coppola,Damon P (2009), Communicating Emergency Preparedness: strategic for creating a disaster resilient, AuerbachPublicationa Taylor \& Francis Group, USA

Ozerdamdkk (2006), Disaster Management and Civil Society Relief in Japan, Turkey and India, London, Itauris Co Ltd

Quarantelli,E.L, (1987), Disaster Studies: An Analysis of The Social Historical Factors Affecting in The Development of Research in The Area, International Journal of Mass and Disaster Ageniceies, Vol 5, pp 285-310

Sinulingga, Anita Afriani, Apriwan, Moenir, HaiyyuDarman, (2014), Kepemerintahan Bencana di Sumatera Barat, Jurnal Penanggulangan Bencana, Volume 5, Nomor 2, Tahun 2014 
Vol. 11 No. 1

Valente, Tomas W, (2010), Social Networks and Health, Models, Methods and Application, Oxford University Press, New York.

Varda, Daniele M Rich (2008) Social Network Methodology in The Study of Disaster: Issues and Insigths Prompted by Post Katarina Research, ForgetteCdavid Banks Noshir Contractor Springer Science + Business Media B V

Wardyaningrum, Damayanti (2016), Jaringan Komunikasi dalam fase Mitigasi Bencana (Analisa Struktur dan Kekuatan Ikatan Lemah (Weak Ties) pada Jaringan Komunikasi Masyarakat di Wilayah Rawan Bencana Gunung Berapi), (disertasi) Departemen Ilmu Komunikasi Universitas Indonesia, Jakarta.

Wardyaningrum, Damayanti (2016), Modal Sosial dalam Jaringan Komunikasi Bencana, Jurnal Komunikasi, Asosisasi Pendidikan Tinggi Ilmu Komunikasi (ASPIKOM), Volume 3, No. 1. 